ДІАЛОГІЧНЕ МОВЛЕННЯ ЯК КЛЮЧОВИЙ АСПЕКТ У ПРОЦЕСІ НАВЧАННЯ ІНОЗЕМНОÏ МОВИ У ПРОФЕСІЙНІЙ ПІДГОТОВЦІ МАЙБУТНІХ ФАХІВЦІВ МОРСЬКОЇ ГАЛУЗІ

\title{
DIALOGICAL SPEECH AS A KEY ASPECT IN THE PROCESS OF FOREIGN LANGUAGE PROFESSIONAL TRAINING OF FUTURE SEAFARERS
}

Необхідність спілкування між людьми з різними мовами, культурами та традиціями $\epsilon$ дуже важливою для професійних рис майбутніх моряків. Нині у методиці навчання іноземних мов майбутніх моряків загальновизнаним вважається комунікативний підхід, основу якого визначає положення про те, що фрормування мовленнєвих умінь повинно відбуватися в умовах, наближених до умов природної комунікації. Отже, комунікативний принцип, як випливає з його назви, безпосередньо спрямований на практику спілкування. У статmі досліджено реалізацію комунікативного принципу, а саме діалогу, що має на меті імітувати реальний прочес спілкування для формування професійних якостей майбутніх моряків. Але дослідження діалогу неможливе без врахування цілої низки немовних чинників: мети і предмета висловлювань, відносин між співрозмовниками і ставлення їх до висловлюваного, ступеня підготовленості співрозмовників до конкретної обстановки спілкування. Характер діалогічної мови визначається дією всіх цих чинників у сукупності, і в результаті конкретного прояву кожного з них створюється діалог певної структури. Особливо діалогічне спрямування стає в чентрі уваги для можливості покращувати мовні навички для використання іноземної мови як засобу комунікації в майбутній професійній діяльності. Комунікативна спрямованість сучасної методики стимулює переглянути традиційні погляди на педагогічні явища. Розроблення методики навчання англійського діалогічного мовлення курсантами або студентами майбутніми фрахівцями морської галузі спрямоване на визначення принципів, методів і засобів навчання, створення системи вправ, які б відповідали специфіці навчання майбут ніх фрахівців морської галузі та реалізації комунікативного підходу до навчання. Розглянуто суть діалогічного мовлення як найефективнішого методу формування іншомовної комунікативної компетениії. Проаналізовано дослідження щодо навчання діалогічного мовлення у праці вітчизняних і закордонних науковців. Детально представлено підготовку до діалогічного спілкування, що відбувається за допомогою певних етапів. Звернуто увагу на вагомості ролі типових видів мовних стимулів у навчальній бесіді.

Ключові слова: комунікативний принцип, діалогічне мовлення, майбутні фрахівці морської галузі, діалог, професійна підготовка, спілкування.
The need for communication between people with different languages, cultures and traditions is very important for the professional qualities of future seafarers. At present, the method of teaching foreign languages of future seafarers is widely recognized as a communicative approach, the basis of which is the provision that the formation of speech skills should occur in conditions close to the conditions of natural communication. Therefore, the communicative principle, as its name implies, is directly aimed at the practice of communication. In the article the implementation of the communicative principle, namely dialogue that aims to simulate a real communication process to form professional qualities of future seafarers are analyzed. But the study of dialogue is impossible without taking into account a number of non-linguistic factors: the purpose and object of the utterances, the relations between the interlocutors and their relationship to the utterance, the degree of readiness of the interlocutors to a specific communication environment. The nature of dialogic language is determined by the action of all these factors in the aggregate, and as a result of the specific manifestation of each of them creates a dialogue of a certain structure. Especially dialogue is placed in the center of consideration for the ability to improve language skills to use foreign language as a means of communication in future professional activities. The communicative principle of modern methods stimulates the revision of traditional views on pedagogical phenomena. Development of methodology for teaching English dialogues to cadets or students - future professionals in the maritime industry is aimed to define principles, methods and training tools, to create a system of exercises that would meet the training specification of future professionals in the maritime industry and to implement a communicative approach to training. Essence of dialogical speech is considered as the most effective method to form foreign language communicative competence. Researches of the dialogical speech teaching in the work of native and foreign scholars were analyzed. Preparations for dialogic communication that take place throughout certain stages are detailed. Attention is paid to the importance of the role of typical types of language incentives in the educational conversation.

Key words: communicative principle, dialogical speech, future professionals in the maritime industry, dialogue, professional training, communication.
Постановка проблеми в загальному вигляді. Проблема навчання іноземної мови за професійним спрямуванням на сучасному етапі розвитку вищої технічної освіти є особливо актуальною, оскільки зміни, які відбуваються в характері освіти, все чіткіше зорієнтуються на вільний розвиток особистості майбутнього фрахівця морської галузі, його самостійність, конкурентоспроможність і мобільність. Відомим $€$ те, що основною метою мовного навчання курсантів/студентів у вищих навчальних закладах $€$ підготовка фрахівця фрлоту до практичного володіння іноземною мовою, що дасть йому змогу ефективно працювати зі спеціалізованими іншомовними джерелами, спілкуватися 3 
колегами, розуміти практичні проблеми, які спрямовані на щоденне та професійне спілкування, складати мовленнєву контекстуальність, ділові листи іноземним колегам, виконувати письмові та усні переклади документів/текстів за профресійним спрямуванням. У межах нашого дослідження завданням навчання іноземної мови курсантів/ студентів - майбутніх фрахівців морської галузі, вважаємо практичне володіння англійською мовою на рівні, необхідному для професійного спілкування через розвиток умінь діалогічного мовлення в процесі мовленнєвої взаємодії в межах професійно-ситуативного контексту, спрямованого на активізацію мислення, розвиток пізнавальних здібностей і фрормування освітньої автономії. Визначені цілі та завдання навчання безпосередньо впливають на вибір змісту навчання діалогічного мовлення курсантів/студентів - майбутніх фрахівців морської галузі.

Аналіз останніх досліджень і публікацій. Теоретичну основу авторського дослідження становлять ключові положення вітчизняної методики навчання іноземних мов, представлені в роботах науковців Н. Скаткіна, І. Біма, Н. Геза, Г. Рогової, які приділяють значну увагу впровадженню принципів професійної спрямованості, рефлективної активності та комунікативності у навчання англійської мови за професійним спрямуванням; положення теорії мовної діяльності, розробленої Л. Виготським, Н. Жінкіним, О. Леонтьєвим, І. Зимньою; результати сучасних досліджень у психології мислення (О. Тихомиров, П. Пономарев) про стильові і продуктивні аспекти інтелектуальної діяльності (В. Колга, Т. Мелентьєва, І. Шкуратова, М. Холодна).

Для визначення дидактичних умов, що активізують продукування діалогічного мовлення в процесі навчання майбутніх фрахівців морської галузі, були проаналізовані праці педагогів, лінгвістів і науковців, присвячені впливу когнітивної психології, що досліджує глибинні процеси пізнавальної діяльності (J. Adams, T. Buzan, D. Cohen, P. Freire, E. Harris, A. Maslow, J. Newson, N. Postman, S. John, J. Wilson), та використання різних стилів і стратегій навчально-пізнавальної діяльності через наслідування принципів комунікативного підходу (M. Boyce, A. Costa, R. Ellis, P. Foster, H. Gardner, K. Johnson, S. Krashen, M. Lipman, B. Moore, D. Stein, M. Swain, M. Thomas).

Виділення не вирішених раніше частин загальної проблеми. Незважаючи на досить широке висвітлення в сучасній лінгводидактиці, проблеми навчання іноземної мови для професійно-орієнтованого спілкування, використання активних методів навчання діалогічного мовлення для майбутніх фрахівців морської галузі потребує уваги дослідників, що й зумовлює актуальність дослідження. Саме тому розгляд цього питання в контексті сучасних інтеграційних процесів в освіті набуває особливої актуальності і значущості.

Мета статті - аналіз складових компонентів змісту діалогічного навчання англійської мови з урахуванням професійного напряму підготовки фрахівців морської галузі, визначення комунікативних ситуацій професійної діяльності, комунікативних ролей і намірів, а також надання типології стратегій, що скеровані на підвищення ефективності навчання усного діалогічного мовлення курсантів або студентів.

Виклад основного матеріалу. Процес навчання може бути описаним як організована система 3 властивими їй складниками. Такими складниками є цілі навчання, що зумовлюють завдання для їх реалізації; які, у свою чергу, базуються на змісті навчання, організованому за загальнодидактичними та методичними принципами; які через засоби навчання, технології та прийоми забезпечують досягання поставлених цілей. Визначені цілі та завдання навчання безпосередньо впливають на вибір змісту навчання діалогічного мовлення.

Сучасне життя показує, що потреба вступати в діалогічний контакт пов'язана з певним мотивом і мовленнєвим завданням, в реалізації яких проявляється ініціатива в певного учасника діалогу. Тому, не відходячи від навчального процесу, слід зазначити, що заняття з іноземної мови розглядається як діяльність спілкування [6, с. 125]. На думку В. Желяскова, це означає відмову від домінування на заняттях формальних мовних вправ на користь діяльнісно й інтелектуально-орієнтованих завдань, які дають змогу вивчати іноземну мову як основний засіб міжкультурного спілкування в процесі діалогу [5, с. 180]. В межах однієї статті вважаємо неможливим зробити детальний аналіз усіх компонентів змісту навчання, тому зосередимося на визначенні комунікативних ситуацій професійної діяльності, комунікативних ролей, мети спілкування, фрункціональних типах діалогів і дискурсивних стратегіях, впровадження яких буде сприяти розвитку вмінь діалогічного мовлення.

Під час вибору тем для спілкування, розподілу мовленнєвих умінь у змісті кожної теми, визначення потенційних ролей курсантів до уваги слід брати професійні потреби курсантів. Відбір професійно-орієнтованих ситуацій проводився нами 3 урахуванням вимог типової програми викладання англійської мови для професійного спілкування, міжнародних визнаних стандартів навчання IM, описаних у Загальноєвропейських Рекомендаціях із мовної освіти [2], робочої програми з англійської мови для бакалаврів, а також вимог Модельного Курсу 3.17 (Maritime English) Міжнародної Морської Організації (IMO) [7] до рівня фрормування комунікативної компетентності 3 англійської за професійним спрямуванням відповідно до стан- 
дартів міжнародного Кодексу ПДМВ 3 Манільськими поправками 2010 року (STCW) [4].

Аналіз зазначених документів дав змогу виокремити типові професійні обов'язки, які вимагають уміння діалогічного мовлення і $є$ основою для формування професійної компетенції, а саме: роботу 3 навігаційними картами та морськими публікаціями, забезпечення безпеки життєдіяльності судна, команди та вантажу; несення вахти, вантажні операції.

Були розроблені навчальні профресійно-орієнтовані ситуації, скеровані на формування вищезазначених професійних компетентностей курсантів:

1) обмін персональною інфрормацією під час знайомства з екіпажем, перевірка коректності прокладки курсу і в разі необхідності його корекція;

2) аналіз дій екіпажу в аварійних ситуаціях;

3) отримання та обговорення метеорологічної інформації;

4) вибір якірної стоянки й прогнозування можливих ускладнюючих обставин;

5) запуск головного двигуна для початку маневрів:

6) обговорення й планування вантажних робіт;

7) перемови при бункерній операції;

8) перемови 3 лоцманською станцією для забезпечення безпечного входу в порт.

У процесі взаємодії у вищезазначених ситуаціях курсанти розвивають уміння діалогічного мовлення та тренують різні мовленнєві функції, а саме; реагувати на зауваження співрозмовника, доповідати 3 конкретними цілями професійного характеру, висловлювати думки, вести перемовини, чітко аргументувати свою думку, спонукати до дії, виражаючи різний ступінь необхідності, тощо. У контексті стандартів Кодексу ПДНВ з Манільськими поправками 2010 року випускник - фрахівець морської галузі має досягнути експлуатаційного (operational) або управлінського (managerial) рівнів володіння мовою [4], набувши таких мовленнєвих умінь у діалогічному мовленні: розпитати, попросити, запропонувати, повідомити, описати, розповісти, пояснити, оцінити, заперечити, підтвердити, обґрунтувати. Під час нашого дослідження було виокремлено комунікативні функції діалогічного мовлення в межах професійної діяльності майбутнього фрахівця морської галузі, а саме: запиту інфрормації - повідомлення інформації - підтвердження отримання інформації; пропозиції (у фрормі прохання, наказу, поради) прийняття/неприйняття запропонованого; обміну судженнями/думками/враженнями; взаємопереконання/обґрунтування своєї позиції.

Мовленнєві професійно орієнтовані вміння: оформлювати вантажний план, вести перемови 3 агентом, демонструючи знання принципів розміщення контейнерів на палубі і в трюмах, уточнювати, пропонувати альтернативні рішення, аргументувати.
Представлені професійно орієнтовані теми спілкування, комунікативні ситуації та мовленнєві вміння зумовлюють відбір текстів, які становлять наступний компонент змісту навчання. Враховуючи досвід методистів, зокрема Е. Оніщенко, Е. Верещагіна, Н. Боріско, С. Николаєвої, В. Скалкіна, С. Фоломкіної, Т. Сєрової щодо відбору текстів для розвитку професійно спрямованої комунікативної компетенції, ми виділяємо такі основні принципи відбору текстового матеріалу, як: тематична цілісність, професійно інформативна значимість, проблемність і ситуативність, жанрова достатність, а також функціональна спрямованість.

Відомо, що мовленнєва поведінка кожного учасника діалогу значною мірою зумовлюється мовленнєвою поведінкою партнера. Саме тому діалогічне мовлення неможливо спланувати заздалегідь, на відміну від монологічного. Обмін репліками відбувається досить швидко і реакція вимагає нормального темпу мовлення. Саме це й зумовлює спонтанність, тобто непідготовленість мовленнєвих дій. Тому діалогічне мовлення має двосторонній характер. Спілкуючись, співрозмовник виступає в ролі мовця, слухача, який повинен реагувати на репліку співрозмовника.

Отже, у курсантів/студентів необхідно розвивати вміння ініціативно розпочинати діалог, реагувати на репліки співрозмовника та спонукати його до дії. На думку В. Артемова, у діалогічному мовленні часто вживаються слова, які служать для підтримки розмови, для заповнення пауз у ній, наприклад, коли мовець підшукує відповідну репліку. Наприклад: well, well now, уou know, let me see, look here, I say. Будь-який діалог складається 3 окремих висловлювань. Такі висловлювання називаються реплікою. Перша репліка діалогічної єдності є завжди ініціативною (ії називають ще реплікою-спонуканням або керуючою). Друга репліка може бути повністю реактивною (інакше залежною, або реплікою-реакцією) [1, с. 122].

Під час навчання діалогічного профресійного мовлення виникають дві основні проблеми: чого вчити, які особливості діалогічного мовлення слід враховувати і як вчити. Перша проблема, у свою чергу, належить до питання про відбір мовного і мовленнєвого матеріалу під час навчання діалогічного мовлення; а друга - до питання про ефрективні й оптимальні форми, методи та прийоми навчання.

Враховуючи особливості професійного спрямування майбутніх фахівців морської галузі, для ефрективного навчання діалогічного мовлення вважаємо за доцільне навчати курсантів таких респонсивних стратегій: співпраці (застосування тактики переконання, ствердження, пропозиції, поради); конкуренції (втілення тактики попередження, погрози, вимоги, осуду та обвинувачення); пристосування (тактика поступки, часткової згоди); ухилення (уникнення відповіді на запитання, зміна 
теми, ігнорування) [3, с. 214]. Під час нашого дослідження було розроблено навчальні професійно-орієнтовані ситуації, спрямовані на розвиток вищезазначених стратегій.

Наведемо приклади деяких із ситуацій.

Situation 1

You are assistant engineer. Sudden breakdown of the main engine. Discuss with your subordinates a plan of actions to fix out the problem, ask about the versions of why this happened, make changes to the plan of actions, argue your decision (adaptation strategy: tactics of assignment, partial agreement).

Situation 2

You are the officer in charge of preparation the documents for the vessel's departure. Discuss with the agent question about filling in the forms offered by the agent of the company, make changes in filling in data, justify your decision (adaptation strategy: tactic of concession, partial agreement).

Situation 3

You are the captain. Vessel is under pilotage. You do not agree with the pilot's actions. Contact Coastal Station (Competition Strategy: Warning, Threats, Demands and Charges).

У структурі навчальної бесіди можна виділити деякі складові частини: - тема бесіди; - експозиція; - ключові слова; - мовна реакція - висловлювання учасників. Навчальна бесіда може бути різноманітною за своєю тематикою. Прогнозуючи мовну реакцію курсантів/студентів і пов'язані 3 нею лексичні труднощі, викладачу слід підготувати низку ключових слів і висловів, які можуть знадобитися у роботі. Ці слова повинні бути відомими, засвоєні курсантами/студентам раніше. Їхнє призначення - бути опорою, підказкою у разі необхідності.

Комунікативна спрямованість - це провідний принцип навчання діалогу, як і усного мовлення загалом. Він включає цілу низку основних вимог, зокрема: 1) комплектування лінгвістично виправданого мінімуму мовного інвентарю, що забезпечує рівень комунікативної достатності; 2) оцінку кожного мовного здобутку, що включається в програму, з погляду реальності його появи в природних актах усного спілкування; 3) фрормування ситуативно-тематичного мінімуму з урахуванням інтересів і майбутніх потреб тих, яких навчають; 4) комунікативність мовних операцій під час роботи над мовним матеріалом (у всіх випадках, коли це можливо); 5) створення визначеної системи роботи, мотивованою потребою в мовному спілкуванні досліджуваною мовою. Формування вміння вести бесіду належить до однієї 3 найважливіших проблем методики навчання іноземної мови.

Етап передавання інфрормації $€$ своєрідним потенціалом для аргументування, оскільки відбувається уточнення змісту проблеми і мети спілкування, обговорення проблеми, передавання інфрормації, іï закріплення і визначення нового напряму інформування. У процесі спілкування співрозмовники детальніше ознайомлюються з можливостями і намірами партнера щодо обговорюваної проблеми. На цьому етапі бажано утримуватися від оцінювання, а натомість застосовувати тактику запитань із метою переходу від монологу до діалогу. Основними елементами цього етапу $є$ такі: 1) фрормування питань (закритих, відкритих, риторичних, питань для роздумів, переломних); 2) вислуховування (концентрація на темі бесіди і на співрозмовникові); 3) вивчення реакцій співрозмовника (спостереження. підтримка візуального контакту); 4) передавання інорормації співрозмовника (застосовування мистецтва дипломатії, створення передумов для аргументації). Це сприяє встановленню взаєморозуміння, довіри та налаштовує на позитивне розв'язання проблеми. Після сприйняття діалогу на слух і в графрічній фрормі курсанти/студенти повинні виконати тест, що покаже міру розуміння діалогу. Цей тест є на зіставлення, під час його виконання курсанти/студенти підбирають до персонажів діалогу їхні репліки. Після цього відбувається аналіз діалогу, що полягає у виявленні його специфрічних особливостей: звертань, що містяться в тексті, розмовних кліше, еліптичних речень. Далі курсанти/студенти розігрують діалог близько до тексту (третій етап). Бажано, щоб вони робили це по пам'яті, тому до кожного виконавця додаються «підказки», що надають курсантам/студентам репліки, дивлячись у книгу, якщо для них це складно. Нарешті, курсантам/ студентам пропонуються нові ситуації (четвертий етап); вони створюються шляхом зміни окремих її компонентів [10]. При цьому курсантам/студентам потрібно дати опори, на основі яких здійснюється діалогічне спілкування.

Висновки. Уміння вести професійний діалог не $€$ результатом формування окремих умінь, воно вирощується як найнеобхідніше уміння навчального співтовариства. Кропітка праця співтовариства курсантів/студентів і викладача дає потрібні результати - у кінці курсу вивчення іноземної мови за професійним спрямуванням курсанти/студенти вже можуть спілкуватися іноземною мовою один з одним (а в майбутньому - 3 іноземними мовцями) на побутові та професійні теми. Але необхідно створити умови, за яких курсанти матимуть бажання і необхідність щось сказати, передати почуття, обговорити і сприятливий психологічний клімат в аудиторії, дружні стосунки. Метою оптимізації навчання іноземної мови на засадах комунікативного підходу майбутніх фрахівців морської галузі вважаємо доцільним організувати активне залучення до взаємодії в навчальних профресійноорієнтованих ситуаціях. Такий підхід сприятиме ефрективності навчання діалогічного мовлення, посиленню мотивації до навчання англійської 
мови, активізації когнітивної самостійності студента та ефективній організації індивідуального й колективного навчання.

\section{БІБЛІОГРАФІЧНИЙ СПИСОК:}

1. Артемов В.А. Обучение диалогической речи (на материале английской речи) : пос. для учителей. Киев : Советская школа, 1989. 123 с.

2. Загальноєвропейські рекомендації 3 мовної освіти: вивчення, викладання, оцінювання / наук. ред. укр. вид. док. пед. наук, проф. С.Ю. Ніколаєва. Київ : Ленвіт, 2003. 273 с.

3. Лук'янець М.Г. Класифікація респонсивних стратегій і тактик (на матеріалі англомовного діалогічного дискурсу). Науковий вісник кафредри ЮНЕСКО Київського національного лінгвістичного універcumeту. Філологія, педагогіка, психологія. 2015. Вип. 30. с. 213-218.
4. Міжнародна конвенція про підготовку і дипломування моряків та несення вахти 1978 року (ПДНВ) International Convention on Standards of Training, Certificating and Watchkeeping for Seafarers, 1978 (STCW 78). Офріційний вісник України. 2009. № 60. Ст. 2148.

5. Желясков В.Я. Теоретичні і методичні засади підготовки майбутніх бакалаврів судноводіїв до профресійної комунікації. Освітньо-наукове забезпечення діяльності складових сектору безпеки $i$ оборони України : тези XI Всеукр. наук.-практ. конфр., м. Хмельницький, 15 листопада 2018 р. 904 с.

6. Мартинова Р.Ю. Цілісна загально дидактична модель змісту навчання іноземних мов : монографрія. Київ : Вища школа, 2004. 454 с.

7. IMO Model Course 3.17. Maritime English. London : International Maritime Organization (IMO), 2010. 138 p. 